\title{
Enhancement of Leaf Rust Resistance of Siberian Winter Wheat Varieties by Marker-assisted Selection
}

\author{
I.N. Leonova*, A.I. Stasyuk, E.S. Skolotneva and E.A. Salina \\ Federal Research Center Institute of Cytology and Genetics SB RAS, Novosibirsk, 630090, Russia
}

(Received 13 March 2017; Accepted 10 May 2017;

Communicated by J. Kolmer)

\begin{abstract}
Cultivation of winter wheat varieties in the West Siberian region of Russia has competitive advantages compared to spring varieties: utilization of spring-summer moisture, early maturation and harvest and a high yield potential. The poor resistance of winter varieties to foliar diseases results in significant yield losses and facilitates the spread of pathogens to the spring wheat cultivars. The present study was conducted to evaluate the effectiveness of molecular markers specific for $V R N-1$ and $L r$ loci in selecting winter wheat genotypes resistant to leaf rust. The winter wheat cultivars Biyskaya ozymaya and Filatovka were crossed with spring wheat introgression lines 21-4 and 5366-180 and the spring wheat cultivar Tulaikovskaya 10 carrying LrTt2, LrAsp5 and Lr6Ai\#2 loci from Triticum timopheevii, Aegilops speltoides and Thynopyrum intermedium, respectively. To identify winter wheat plants homozygous for target loci, $\mathrm{F}_{2}$ populations were screened with functional markers to $V R N-1$ genes and with markers specific for alien genetic material. Based on the genotyping analysis of $371 \mathrm{~F}_{2}$ plants a total of 44 homozygous genotypes with winter habit was identified. There were eight genotypes containing $L r$ loci among them. Evaluation of $\mathrm{F}_{2}$-derived $\mathrm{F}_{3-4}$ families for both seedling and adult resistance showed that only one $\mathrm{F}_{3-4}$ family had moderate susceptible reaction type to the field population of leaf rust. Others ranged from nearly immune to resistant with severity of $5 \%$. The data also indicated the utility of the $V R N-1$ allele-specific markers for detection of genotypes with winter habit without vernalization at early stages of plant breeding.
\end{abstract}

Keywords: winter and spring wheats, leaf rust, $V R N-1$ genes, $L r$ genes, marker-assisted selection

\section{Introduction}

Western Siberia is among the leading grain-producing regions in the Russian Federation. Traditionally spring bread wheat is dominant in Western Siberia due to its cold climate and extreme winter temperatures. However, the climate changes in recent decades has expanded winter wheat production in Siberia. While spring wheat dominates in Siberia, winter wheat increased its acreage approximately 10 percent during last years. In general, winter wheat has some advantages over spring wheat: a higher yield potential, utilization of spring moisture, resistance to spring-summer droughts, and early harvest under more

*Corresponding author, E-mail: leonova@bionet.nsc.ru 
favorable weather conditions at the end of July - the beginning of August, compared to spring wheats harvested in September-October. Cultivation of winter wheats in regions with short vegetation period, allows a reduction of the field work load during sowings in spring and in autumn during harvesting.

The modern varieties of winter wheat adapted to the Western Siberian steppe and mixed forest are characterized by high yield, good quality of grain and flour, frost tolerance and successful overwintering. However, most of them lack effective resistance to foliar diseases, which may result in significant crop losses and allowing diseases to spread to the spring wheat as well. Leaf rust caused by the fungus Puccinia triticina Eriks. is important disease for Western Siberia and all over the world. Annual yield losses are about $10-15 \%$ and can exceed $40-50 \%$ during the outbreaks when the weather conditions favor the pathogen (Sanin and Nasarova 2010). Thus, the development of durable genetic resistance to leaf rust should be among the priority objective of winter wheat breeding program in Western Siberia.

Growing resistant cultivars is the most efficient, cost-effective and environmentfriendly approach for crop protection against fungal pathogens. More than $80 \mathrm{Lr}$ (leaf rust resistance) genes assigned temporary or catalog symbols have been already identified in bread wheat and its relatives (McIntosh et al. 2013). However, only a few alien $L r$ genes are involved in wheat breeding for development of resistant varieties due to the negative effects of alien genetic material on agronomically important traits. The majority of Russian winter and spring cultivars are protected against leaf rust by relatively few $L r$ genes including $\operatorname{Lr}$ 9, $\operatorname{Lr} 10$, $\operatorname{Lr} 19$, $\operatorname{Lr} 23, \operatorname{Lr} 24$, and $\operatorname{Lr} 26$. The resistance of Western Siberian spring wheat cultivars is provided by slightly effective genes $\operatorname{Lr} 3, \operatorname{Lr} 10, \operatorname{Lr} 13$ and genes $\operatorname{Lr} 9, \operatorname{Lr} 19, \operatorname{Lr} 23$, and $L r 26$ with resistant or moderate susceptible responses depending on the year (Morgounov et al. 2011; Gultyaeva et al. 2012). In contrast to the spring wheat, winter wheat varieties cultivated in the Siberian region, do not contain $\mathrm{Lr}$ genes that provide effective resistance to leaf rust.

The cultivation of genetically homogeneous cultivars enhances vulnerability to biotic stresses due to the selection of virulent races and accumulation of pathogen inoculum in the field. In the case of leaf rust, the data of race surveys in 2006-2014 and screening for resistance of cultivars released in the different regions of Russia showed that the efficiency of $\mathrm{Lr}$ genes used overall was decreasing or they were not effective at all (Gultyaeva et al. 2012; Kolmer et al. 2015). Virulence to $\operatorname{Lr} 9$, $\operatorname{Lr} 23$ and $\operatorname{Lr} 19$ genes important for Western Siberian germplasm was observed recently with an increase of $P$. triticina races virulent to $\operatorname{Lr} 19$ (Gultyaeva et al. 2015). In Russian Federation winter wheat cultivars resistant to leaf rust are adapted to the Volga, Central Black Earth, North Caucasus regions and other areas with a mild climate but not to Western Siberia. To compensate the decreasing list of effective $L r$ genes it is necessary to search for new resistance genes and integrate them into breeding programs related to winter wheat varieties.

Conventional method for identification of resistant genes involves the evaluation of infection types on seedlings and adult plant inoculated with $P$. triticina isolates with known virulence to leaf rust resistance genes (Roelfs et al. 1992). All these procedures are time consuming and require laboratory support for fungal isolates and wheat lines. Now- 
adays an alternative approach based on molecular technology is widely used for genotyping, and specific DNA molecular markers are developed for many resistant genes providing for the marker-assisted selection (MAS) and the introgression of targeted genes into the commercial cultivars and breeding lines (Xu 2010).

Here we presented the results of the introduction of new leaf rust resistance genes into the winter wheat cultivars adapted to Western Siberia environments. The spring bread wheat lines with LrTt2 and LrAsp5 from Triticum timopheevii (Timonova et al. 2013) and Aegilops speltoides (Petrash et al. 2016) and the spring bread wheat cultivar Tulaikovskaya 10 with Lr6Ai\#2 from Thynopyrum intermedium (Salina et al. 2015) were used as donor parents for resistance. The transfer of $L r$ genes into the recipient winter wheat cultivars was facilitated with specific markers for alien genetic material carrying the resistant genes. Finally, for identification of winter genotypes in crosses of winter and spring wheat lines it was essential to use the molecular markers developed for the different alleles of VRN-1 (Yan et al. 2004; Fu et al. 2005; Shcherban et al. 2012).

\section{Materials and Methods}

\section{Plant material and marker-assisted selection}

The winter wheat varieties Filatovka and Biyskaya ozymaya adapted to Western Siberia were used as female parents to produce the hybrids. Together with productivity and high protein content, these varieties express resistance to abiotic stresses. However, they are sensitive to the most pathogen races of leaf rust. The following donor parents for resistance were used: 1) the spring common wheat introgression line 21-4 with translocation from Ae. speltoides (T5BS.5BL-5SL); 2) the spring common wheat introgression line 5366-180 containing translocation from T. timopheevii (T5BS.5BL-5GL); 3) the spring bread wheat cultivar Tulaikovskaya 10 with substitution of $6 \mathrm{D}$ chromosome on chromosome 6Ai\#2 of wheatgrass Thinopyrum intermedium. They carry LrAsp5, LrTt2, and Lr6Ai\#2 loci protecting bread wheat against leaf rust (Timonova et al. 2013; Salina et al. 2015; Petrash et al. 2016). The total of 371 progenies in six $F_{2}$ populations were produced by crossing the recipient winter wheat cultivars with the leaf rust resistant donors. Populations of $\mathrm{F}_{2}$ seedlings were simultaneously genotyped with molecular markers specific for different alleles of $V R N-1$ loci and for alien genetic material containing $L r$ genes. $\mathrm{F}_{2}$ plants were self-pollinated and $\mathrm{F}_{3-4}$ families were evaluated for growth habit, winter hardiness and leaf rust resistance in field trials during 2014-2016.

\section{DNA extraction and PCR}

Genomic DNA was isolated from 5-7-day-old seedlings as described by Kiseleva et al. (2016). PCR primers reported in Yan et al. (2004), Fu et al. (2005) and Shcherban et al. (2012) were used to detect the presence of dominant or recessive alleles of $\mathrm{Vrn}-\mathrm{A1}$, $\mathrm{Vrn}$ $B 1$ and $V r n-D 1$ genes. List of PCR primers for alien genetic material containing $L r$ loci from Ae. speltoides, T. timopheevii and Th. intermedium is presented in Table 1. PCR 
Table 1. PCR primers for identification of alien fragments containing $L r$ resistance genes

\begin{tabular}{|l|c|l|c|c|c|}
\hline Lr gene & Marker name & Marker structure & $\begin{array}{c}\text { Annealing } \\
\text { temp. }\left({ }^{\circ} \mathrm{C}\right)\end{array}$ & $\begin{array}{c}\text { PCR } \\
\text { fragment } \\
\text { (bp) }\end{array}$ & Reference \\
\hline LrAsp5 & $\begin{array}{l}\text { Pr1 } \\
\text { Pr5 }\end{array}$ & $\begin{array}{l}\text { TACCCCTGCTACCAGTGCGC } \\
\text { GGCCAACCCTACACCCCAAG }\end{array}$ & 55 & 968 & $\begin{array}{c}\text { Patent RU } \\
\text { №2535985 }\end{array}$ \\
\hline LrTt2 & Xbarc232 & $\begin{array}{l}\text { F-CGCATCCAACCATCCCCACCCAACA } \\
\text { R-CGCAGTAGATCCACCACCCCGCCAGA }\end{array}$ & 60 & 200,240 & $\begin{array}{c}\text { Song et al. } \\
2005\end{array}$ \\
\hline Lr6Ai\#2 & $\begin{array}{c}\text { MF2/MR1r2 } \\
\text { MF2/MR4 }\end{array}$ & Available on request & 55 & 347 & $\begin{array}{c}\text { Patent RU } \\
\text { №2598275 }\end{array}$ \\
\hline
\end{tabular}

conditions for SSR marker Xbarc232 was as described in Song et al. (2005). PCR mixture and amplification protocols for other primers were as described in Shcherban et al. (2015). The PCR products were separated on $1.5 \%$ agarose gel, stained with ethidium bromide and visualized under ultraviolet light.

\section{Phenotyping}

The adult plant resistance to leaf rust and winter hardiness were evaluated on the experimental plots of Federal Research Center Institute of Cytology and Genetics SB RAS near Novosibirsk during the 2014/15 and 2015/16 growing seasons. The field experiment was carried out in a randomized design with three replicates: $25 \mathrm{~g}$ of seeds of each $\mathrm{F}_{3-4}$ family along with the parental winter wheat cultivars were sown in a plot of $1 \mathrm{~m}^{2}$ in the first week of September. A $1 \mathrm{~m}$ border of highly susceptible winter wheat cultivars Albidum 12 and Dneprovskaya 521 surrounded the plots for disease spread. The spring wheat donors of the resistance genes were planted at the middle of May as additional control. Resistance to leaf rust was evaluated with natural infection of native population of $P$. triticina specific for Western Siberian region. Leaf rust severity was scored using $0-100 \%$ coverage of leaves with rust pustules according to modified Cobb's scale (Peterson et al. 1948).

Seedling response to leaf rust was tested at the greenhouse of the Institute under controlled environmental conditions. Eight-day-old seedlings were inoculated with urediniospores of the field population of $P$. triticina as described by Roelfs et al. (1992). Disease reaction was scored 12 days after inoculation using the scale of Mains and Jackson (1926). Plants with infection types 0,1 and 2 were considered as immune, resistant and moderately resistant, while infection types 3 and 4 were considered moderately susceptible and susceptible. Winter hardiness was estimated at the beginning of the spring season (AprilMay) as the number of surviving plants (in percent). 


\section{Results}

\section{Genotyping of $F_{2}$ populations}

$\mathrm{F}_{2}$ populations derived from crosses between the winter recipient cultivars and spring donors of $L r$ genes were genotyped with allele-specific primers designed for detecting allelic variation of $V R N-1$ genes $(V r n-A 1, V r n-B 1, V r n-D 1)$. The composition of the genes determines the growth habit of wheat plant. Genotypes with of all the recessive alleles $v r n-A 1, v r n-B 1$, and $v r n-D 1$ result in a winter habit and makes the plant sensitive to vernalization while even single dominant allele of any of these loci results in a spring growth habit (Pugsley 1971). For the recipient cultivars Filatovka and Biyskaya ozymaya the recessive alleles were confirmed at all loci (Fig. 1). Allelic combination of Vrn-Ala and $v r n-D 1$ was identified for all the donors of $L r$ resistance which differed for alleles of $V r n$ $B 1$. The breeding line 21-4 carried $v r n-B 1$, the breeding line 5366-180 - Vrn-B1c, and the cultivar Tulaikovskaya $10-\operatorname{Vrn}-B 1 a$ (Fig. 1). A total of 132 individual $\mathrm{F}_{2}$ plants with various combination of homozygous alleles for $V R N-1$ loci were revealed from $\mathrm{F}_{2}$ populations derived from different crosses. Among them 44 plants had the combination of all three recessive alleles (Table 2).

Table 2. Allelic composition of $\mathrm{F}_{2}$ progenies homozygous for $V R N-1$ genes, containing $(L r+)$ and not containing $(\mathrm{Lr}-)$ leaf rust resistance genes

\begin{tabular}{|c|c|c|c|c|c|}
\hline \multirow{2}{*}{ Cross combination } & \multirow{2}{*}{$\begin{array}{l}\text { Number } \\
\text { of } \mathrm{F}_{2} \text { plants }\end{array}$} & \multirow{2}{*}{$\begin{array}{l}\text { Allelic composition } \\
\text { of } V R N-1 \text { loci }\end{array}$} & \multirow{2}{*}{$\begin{array}{l}\text { Number of } V R N-1 \\
\text { homozygo-us plants }\end{array}$} & \multicolumn{2}{|c|}{ Of these } \\
\hline & & & & $\mathrm{Lr}^{+*}$ & $\mathrm{Lr}-$ \\
\hline Filatovka $\times 5366-180$ & 66 & $\begin{array}{l}\text { Vrn-A1a Vrn-B1c vrn-D1 } \\
\text { Vrn-A1a vrn-B1 vrn-D1 } \\
\text { vrn-A1 Vrn-B1c vrn-D1 } \\
\text { vrn-A1 vrn-B1 vrn-D1 }\end{array}$ & $\begin{array}{l}7 \\
2 \\
7 \\
2\end{array}$ & $\begin{array}{l}3 \\
0 \\
6 \\
0 \\
\end{array}$ & \\
\hline $\begin{array}{l}\text { Biyskaya ozimaya } \times \\
5366-180\end{array}$ & 56 & $\begin{array}{l}\text { Vrn-A1a Vrn-B1c vrn-D1 } \\
\text { Vrn-A1a vrn-B1 vrn-D1 } \\
\text { vrn-A1 Vrn-B1c vrn-D1 } \\
\text { vrn-A1 vrn-B1 vrn-D1 }\end{array}$ & $\begin{array}{l}3 \\
3 \\
4 \\
3 \\
\end{array}$ & $\begin{array}{l}2 \\
1 \\
4 \\
0\end{array}$ & \\
\hline Filatovka × 21-4 & 69 & $\begin{array}{l}\text { Vrn-A1a vrn-B1 vrn-D1 } \\
\text { vrn-A1 vrn-B1 vrn-D1 }\end{array}$ & $\begin{array}{l}18 \\
17 \\
\end{array}$ & $\begin{array}{l}6 \\
4 \\
\end{array}$ & $\begin{array}{l}12 \\
13 \\
\end{array}$ \\
\hline $\begin{array}{l}\text { Biyskaya ozimaya } \times \\
21-4\end{array}$ & 55 & $\begin{array}{l}\text { Vrn-A1a vrn-B1 vrn-D1 } \\
\text { vrn-A1 vrn-B1 vrn-D1 }\end{array}$ & $\begin{array}{l}15 \\
14 \\
\end{array}$ & $\begin{array}{l}3 \\
3 \\
\end{array}$ & $\begin{array}{l}12 \\
11 \\
\end{array}$ \\
\hline $\begin{array}{l}\text { Filatovka } \times \\
\text { Tulaikovskaya } 10\end{array}$ & 69 & $\begin{array}{l}\text { Vrn-A1a Vrn-B1a vrn-D1 } \\
\text { Vrn-A1a vrn-B1 vrn-D1 } \\
\text { vrn-A1 Vrn-B1a vrn-D1 } \\
\text { vrn-A1 vrn-B1 vrn-D1 }\end{array}$ & $\begin{array}{c}2 \\
3 \\
10 \\
2 \\
\end{array}$ & $\begin{array}{l}0 \\
1 \\
4 \\
0\end{array}$ & $\begin{array}{l}2 \\
2 \\
6 \\
2 \\
\end{array}$ \\
\hline $\begin{array}{l}\text { Biyskaya ozymaya } \times \\
\text { Tulaikovskaya } 10\end{array}$ & 56 & $\begin{array}{l}\text { Vrn-A1a Vrn-B1a vrn-D1 } \\
\text { Vrn-A1 a vrn-B1 vrn-D1 } \\
\text { vrn-A1 Vrn-B1a vrn-D1 } \\
\text { vrn-A1 vrn-B1 vrn-D1 }\end{array}$ & $\begin{array}{l}3 \\
4 \\
7 \\
6\end{array}$ & $\begin{array}{l}1 \\
1 \\
1 \\
1\end{array}$ & $\begin{array}{l}2 \\
3 \\
6 \\
5\end{array}$ \\
\hline Total number of $F_{2}$ & 371 & & & & \\
\hline Of these genotype & & vrn-A1 vrn-B1 vrn-D1 & 44 & 8 & 31 \\
\hline
\end{tabular}

Bold designates genotypes of donor lines for $V R N-1$.

*Presence/absence of $L r$ genes was postulated based on molecular marker analysis. 

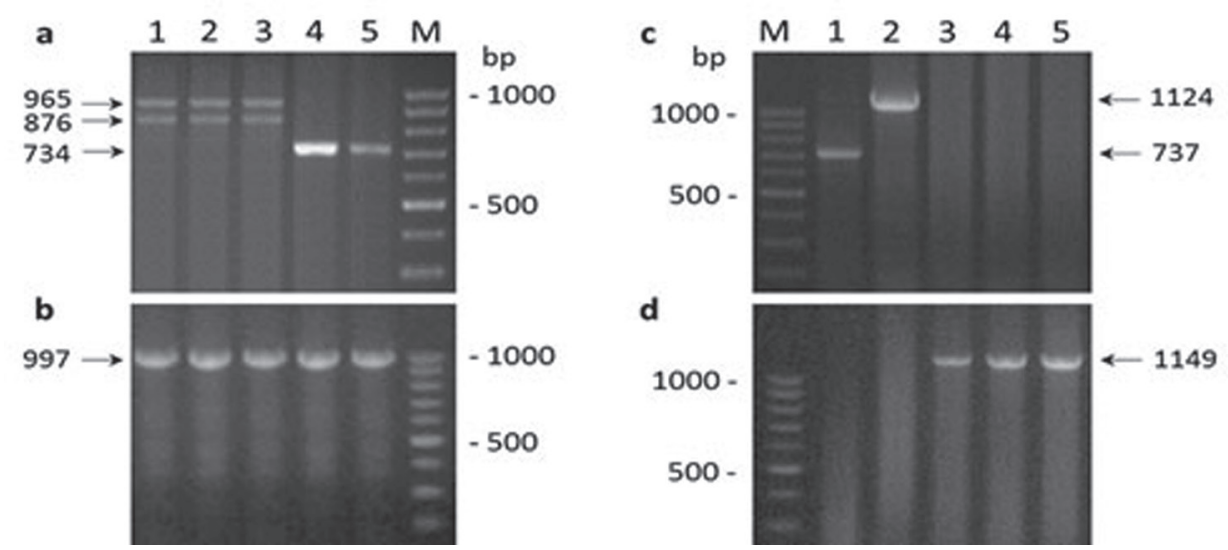

Figure 1. PCR profiles of primers for $V R N-1$ genes in winter wheat varieties and in donors of $L r$ genes: (a) vrn-A1 (734 bp) and VRN-A1a (965+876 bp); (b) vrn-D1 (997 bp); (c) VRN-B1a (1124 bp) and VRN-B1c (737 bp); (d) vrn-B1 (1149 bp). M - DNA ladder of molecular weight marker, lane1 - line 5366-180, lane 2 Tulaikovskaya 10, lane 3 - line 21-4, lane 4 - Filatovka, lane 5 - Biyskaya ozimaya
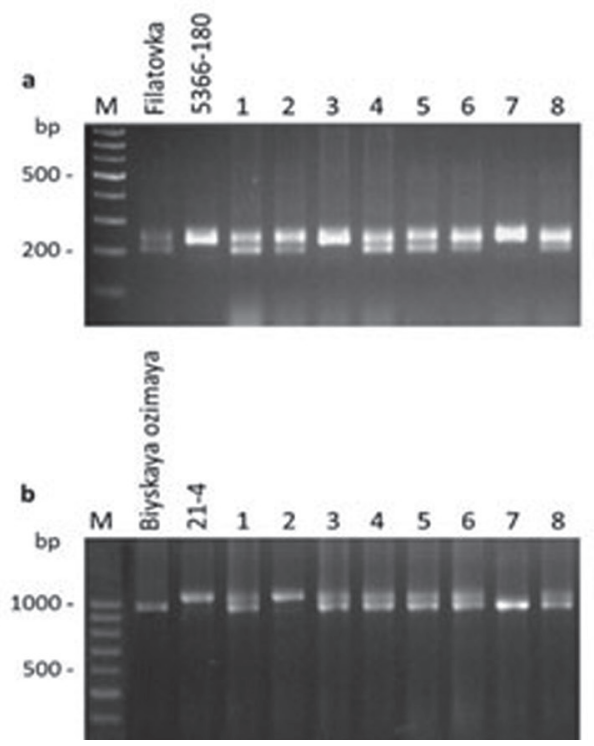
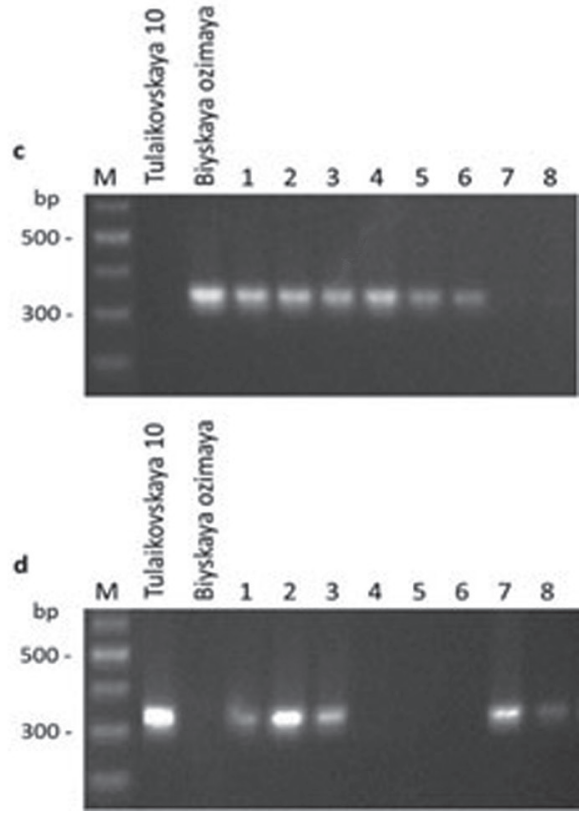

Figure 2. Examples of PCR patterns obtained amplifying genomic DNA of the winter wheat cultivars Filatovka and Biyskaya ozimaya and the donor of $L r$ genes with markers Xbarc232 (a), Pr1/Pr5 (b), MF2/MR4 (c) and MF2/MR1r2 (d). Lane M is DNA ladder of molecular weight marker, lanes $1-8-\mathrm{F}_{2}$ plants 
To identify plants carrying $\mathrm{Lr}$ resistance genes $\mathrm{F}_{2}$ populations were genotyped with primers specific to alien translocations (Table 1). The translocation T5BS.5BL-5GL containing LrTt2 gene from T. timopheevii was detected with SSR marker Xbarc232 posessing two alleles on 5AL and 5BL chromosomes (Somers et al. 2004). For the recipient cultivars both fragments specific to 5AL and 5BL chromosomes, $200 \mathrm{bp}$ and $240 \mathrm{bp}$ in size, were amplified with Xbarc232 (Fig. 2a). There was no 200 bp fragment in the Xbarc232 amplicon of the line 5366-180 carring the T5BS.5BL-5GL translocation. Neither genotypes heterozygous for LrTt2 locus nor genotypes lacking this gene could be identified using the dominant marker Xbarc232. The following selections of individual plants were done after the PCR genotyping: nine spring genotypes homozygous for LrTt2 locus from 66 progenies of $\mathrm{F}_{2}$ population from Filatovka $\times 5366-180$ cross, and seven spring genotypes with $T$. timopheevii translocation from 56 progenies of $\mathrm{F}_{2}$ population of Biyskaya ozimaya $\times 5366-180$ cross. But no winter genotypes carring the $T$. timopheevii introgressions were revealed among the progenies of both crosses.

The STS primers Pr1/Pr5 that cosegregated with leaf rust resistant gene LrAsp 5 from Ae. speltoides were developed to distinguish winter wheat cultivars Filatovka and Biyskaya ozimaya (968 bp fragment) and the donor line 21-4 (1100 pb fragment) (Fig. 2b). After molecular analyses of $\mathrm{F}_{2}$ hybrids from the crosses between the winter wheat cultivars and the line 21-4 with Pr1/Pr5 primers the translocated fragment from Ae. speltoides was identified in 16 individual plants from 124 including 7 winter genotypes (Table 2).

The PLUG markers TNAC1752 and TNAC1674 were used before to identify in the cultivar Tulaikovskaya 10 the chromosome 6Ai\#2 from Th. intermedium carrying the resistant gene Lr6Ai\#2 (Ishikawa et al. 2009). However, application of the PLUG markers required the treatment of PCR products with restriction endonucleases. To overcome this disadvantage we developed the STS primers MF2, MF4, and MR1r2 based on PLUG markers but more suitable for chromosome 6Ai\#2 check. For the cultivar Tulaikovskaya 10 the primer combination MF2/MR1r2 generated the $347 \mathrm{bp}$ fragment that was absent in winter genotypes. Meanwhile another combination MF2/MR4 discriminated the winter cultivars Filatovka and Biyskaya ozimaya amplifying the fragment of 328 bp (Fig. 2c, d). Homozygous or heterozygous plants for Lr6Ai\#2 locus could be identified in multiplex PCR with both primer combinations. Genotyping of $\mathrm{F}_{2}$ populations from the crosses between recipient winter wheat cultivars with Tulaikovskaya 10 with MF2/MR1r2 and MF2/MR4 primers revealed 9 individual plants with alien introgression from Th. intermedium including one winter genotype (Table 2).

Thus, a total of 44 winter wheat genotypes from 371 progenies of $F_{2}$ populations were identified by molecular analysis. Among them there were eight plants carrying the alien genetic material from Ae. speltoides and Th. intermedium as homozygotes.

\section{Evaluation of leaf rust resistance and winter hardiness}

The $\mathrm{F}_{3-4}$ families from eight self-pollinated $\mathrm{F}_{2}$ hybrids recessive for $V R N-1$ gene and containing the LrAsp5 and Lr6Ai\#2 genes were evaluated for winter habit, winter hardiness 
and leaf rust resistance using the recipient winter cultivars and the spring $L r$ donors as control genotypes.

The growing season of 2015/16 had more periods of freezing temperatures (up to $20^{\circ} \mathrm{C}$ ) without snow than the testing period of 2014/15 that affected the overwintering significantly. The cold hardiness of $\mathrm{F}_{3-4}$ hybrids and the parent cultivars Biyskaya ozimaya and Filatovka were similar but only 58\% of plants survived in 2015/16. Independent of hybrid genotypes, there was approximately 95\% survival of plants in 2014/15.

The seedling and adult resistance of $\mathrm{F}_{3-4}$ hybrid families to leaf rust are given in Table 3. For seedling plants, six hybrid families with alien translocations were resistant (ITs $=1$ and 2). The same infection types were observed for the $L r$ donors Tulaikovskaya 10 and 21-4. Meanwhile the seedling score for plants of the recipient winter cultivars was 3 (moderate susceptible).

The adult plant resistance of $\mathrm{F}_{3-4}$ hybrid families was variable for infection types, which was the same for tested genotypes between growing seasons. Five $\mathrm{F}_{3-4}$ hybrid families (74-12, 83-8, 87-12, 87-1, 73-3) were immune or resistant to leaf rust in both field trials of 2014/15 and 2015/16. Two $\mathrm{F}_{3-4}$ families (76-6, 86-4) had moderate resistant reaction type. Only one sample 76-11 was evaluated as moderate susceptible after seedling and adult plant score $(\mathrm{IT}=3)$ but the percentage of diseased leaf was lower than the controls and varied from 5 to $20 \%$ (Table 3 ).

Table 3. Response of winter wheat $\mathrm{F}_{3-4}$ populations, parental wheat varieties and donors of resistance genes to leaf rust at seedling and adult plant stages

\begin{tabular}{|c|c|c|c|c|}
\hline \multirow{3}{*}{ Cross combination } & \multirow{3}{*}{ No. $F_{3-4}$ family } & \multicolumn{3}{|c|}{ Infection type (IT) } \\
\hline & & \multirow{2}{*}{ Seedling } & \multicolumn{2}{|c|}{ Adult plant } \\
\hline & & & $2014 / 15$ & $2015 / 16$ \\
\hline \multirow[t]{3}{*}{ Biyskaya ozimaya $\times 21-4$} & $74-12$ & 1 & 0 & $\operatorname{TrR}$ \\
\hline & $76-6$ & 2 & TrMR & $5 \mathrm{MR}$ \\
\hline & $76-11$ & 3 & $5 \mathrm{MS}$ & 20MS \\
\hline \multirow[t]{4}{*}{ Filatovka $\times 21-4$} & $83-8$ & 1 & 0 & $5 \mathrm{R}$ \\
\hline & $86-4$ & 2 & TrMR & $5 \mathrm{MR}$ \\
\hline & $87-1$ & 2 & 0 & $5 \mathrm{R}$ \\
\hline & $87-12$ & 1 & 0 & $5 \mathrm{R}$ \\
\hline Biyskaya ozimaya $\times$ Tulaikovskaya 10 & $73-3$ & 1 & 0 & 0 \\
\hline Biyskaya ozimaya & & 3 & $65 \mathrm{~S}$ & $80 \mathrm{~S}$ \\
\hline Filatovka & & 3 & $80 \mathrm{~S}$ & $80 \mathrm{~S}$ \\
\hline Tulaikovskaya 10 & & $0-1$ & 0 & 0 \\
\hline $21-4$ & & 2 & $5 \mathrm{MR}$ & $10 \mathrm{MR}$ \\
\hline
\end{tabular}

ITs of seedlings were scored as: 0 - no uredinia, 1 - small uredinia surrounded by necrosis, 2 - small to medium uredinia surrounded by necrosis or chlorosis, 3 - medium uredinia without necrosis and chlorosis, 4 - large uredinia without chlorosis. ITs of adult plant were scored as: $\mathrm{R}$ - resistance, MR - moderate resistance. MS - moderate susceptible, $\mathrm{S}$ - susceptible, 0 immune, $\operatorname{Tr}-$ trace $(<5 \%)$; numeric character means $\%$ of leaf coverage by uredinia. 


\section{Discussion}

The objective of this investigation was to develop the breeding wheat lines with winter growth habit and resistance to leaf rust. A key approach in this study was marker-assisted selection (MAS) linked with target loci to assist genotyping selections in crop improvement. MAS has recently become a routine technique for early generation screening of wheat hybrids for genes conferring agronomically important traits rather than conducting the more labor intensive phenotypic tests. Moreover molecular markers and MAS are broadly applied to enhance the schemes of identification, introgression and pyramiding of fungal disease resistance genes including $\mathrm{Lr}$ genes against leaf rust (Xu 2010; Miedaner and Korzun 2012; Mallick et al. 2015).

For the last two decades the allelic composition of $V R N-1$ genes has been studied by molecular genetic tools. Gene-specific markers and functional markers were proposed to develop isogenic lines and to use them in the genetic analysis of the World Germplasm diversity of wheat, barley, rye, and triticale (Cockram et al. 2009; Nowak et al. 2014). Moreover, the markers linked to the loci of different target traits, which are involved in frost resistance, spike architecture, and the others (Sutka 2001; Deng et al. 2015; Rizza et al. 2016), could also be used to selected germplasm with these traits. In this study, allelespecific markers to $V R N-1$ were used to reveal the genotypes homozygous for recessive alleles from $\mathrm{F}_{2}$ population, which were confirmed by following field trials for winter growth. Our results also demonstrate that functional markers diagnostic for $V R N-1$ genes might be applied in preliminary breeding of winter wheat genotypes without vernalization treatment. This was one of the first attempt to exploit molecular markers to $V R N-1$ loci for MAS breeding of winter wheat.

The predictive value of any markers across a set of breeding lines depends on linkage to the target loci, codominant nature and the presence of recombination events between recipient chromosome and translocated chromosome of donor line. In this study, the molecular markers specific for Ae. speltoides, T. timopheevii and Th. intermedium genetic material were used to detect the leaf rust resistance genes (Table 1). As it was shown earlier, translocated chromosomes of the donor lines have a reduced recombination with T. aestivum chromosomes (Salina et al. 2015; Petrash et al. 2016). Taking into account the partial homoeology between the common wheat chromosomes and the alien chromatin, we suggested the efficiency of the markers to track $L r$ genes in early generations. However, genotyping results indicated that only robust polymorphic markers developed for alien fragments of Ae. speltoides and Th. intermedium were able to identify the homozygous $\mathrm{F}_{2}$ plants with rust resistance genes LrAsp5 and Lr6Ai\#2. The SSR markers Xbarc232 used for detection of LrTt2 gene from T. timopheevii amplified the products only from the winter wheat parents. Determination of homozygous and heterozygous genotypes using the marker Xbarc232 is impossible among the plants from small array of the first generations until the development of the additional marker specific to 5GL chromosome from T. timopheevii.

The resistance of MAS genotypes of $\mathrm{F}_{3-4}$ populations from crosses Filatovka $\times 21-4$ and Biyskaya ozimaya $\times$ Tulaikovskaya 10 was confirmed with the seedling tests (IT 
from 0 to 2; Table 3) and field trials of adult plant resistance excluding the sample of the line 76-11, which expressed the moderate susceptible phenotype at seedling and adult plant stages. This could be result of reduction up to elimination of the introgressed segment after self-pollination of initial $\mathrm{F}_{2}$ plant. Such instances were described in the literature (Olson et al. 2010; Timonova et al. 2013). The lines 83-8, 87-1, and 87-12 with similar responses at the adult plant stage had varying scores for seedlings (Table 3 ). The different genetic basis of juvenile and adult plant resistance may be assumed for the line 87-1. It expressed the moderate resistance at seedling stage $(\mathrm{IT}=2)$ but immune or high resistance response at the adult stage ( 0 or $5 \mathrm{R})$.

The sample size of experimental population depends on the number of analyzed loci and on the type of population. The more genes are investigated, the greater the population size is necessary to identify progenies that contain various gene combinations. The statistical requirement for multigene analysis of $\mathrm{F}_{2}$ population providing by conventional phenotyping selection needed a large sample size for observation. Over several thousands of $\mathrm{F}_{2}$ individual plants should be involved in searching for target genotype which homozygous for three or more unlinked loci controlling single trait (Witcombe and Virk 2001; Baenziger and DePauw 2009). Meanwhile in this study the sample size of 69 individual plants was enough to genotype the homozygous loci using the multiplex PCR with primers to various alleles of $V R N-1$ genes together with codominant markers to $\operatorname{Lr}$ genes.

Hybridization between winter and spring cultivars is important breeding approach to enrich wheat genetic diversity for agronomically important traits. Introgression of the winter wheat gene pool into spring wheat is widely used to develop the spring varieties with high yielding multiflorous spikes and grain quality. From the other hand, the spring germplasm is valuable for breeding for drought tolerance and disease resistance (Kant et al. 2008; Sharma and Chaudhary 2009).

In Russia winter and spring bread wheat breeding programs for wide adaptation and high yield potential involving intra and interspecific hybridization have been conducted since the early $20^{\text {th }}$ century up to the present day. A set of improved winter and spring cultivars originated from the hybridization of the winter cultivars Bezostaya 1, Avrora, Kavkaz with the high yielding spring cultivars with baking quality and drought tolerance (Morgounov et al. 2011). However there are disadvantages of conventional breeding for the winter genotypes from the crosses between the winter and spring cultivars: 1) assessment of the large sample of population to reveal individuals characterized by winter habit; 2) the use of labor-intensive methods to detect winter genotypes in winter $\times$ spring wheat crosses; 3) the long time of phenotypic assessment to differentiate spring and winter forms (Morgounov et al. 1996; Lapochkina et al. 2016). Considering our data of homozygous recessive alleles for $V r n-1$ genes obtaining from small sample, we could approve the application of the allele-specific markers to facilitate the genotyping and to reduce the time taken for selection. Additionally, winter habit for self-pollinated $\mathrm{F}_{2}$ plants was confirmed during field trials.

According to our data, genes LrAsp5 and Lr6Ai\#2 are still effective against Western Siberian population of leaf rust while many of resistant $L r$ genes in local germplasm are 
overcome by new virulent races. Winter wheat derivatives carrying LrAsp5 and Lr6Ai\#2 genes could be used as a source of resistance for development of new adapted wheat cultivars.

\section{Acknowledgements}

We thank the Russian Science Foundation (project no. 16-16-00011) for financial support of this study. We thank the Joint Access Center for Artificial Plant Cultivation supported by the IC\&G Budgetary Project No. 0324-2015-0005. I.N. Leonova and A.I. Stasyuk have contributed equally to this work.

\section{References}

Baenziger, P.S., DePauw, R.M. 2009. Wheat breeding: procedures and strategies. In: Carver, B.F. (ed.), Wheat Science and Trade. Wiley-Blackwell. Oxford, UK. pp. 275-308.

Cockram, J., Norris, C., Donal, M., O’Sullivan, D.M.O. 2009. PCR-based markers diagnostic for spring and winter seasonal growth habit in barley. Crop Sci. 49:403-410.

Deng, W., Casao, M.C., Wang, P., Sato, K., Hayes, P.H., Finnegan, E.J., Trevaskis, B. 2015. Direct links between the vernalization response and other key traits of cereal crops. Nature Commun. 6:5882.

Fu, D., Szücs, P., Yan, L., Helguera, M., Skinner, J.S., Zitzewitz, J.V., Hayes, P.M., Dubcovsky, J. 2005. Large deletions within the first intron in $V R N-1$ are associated with spring growth habit in barley and wheat. Mol. Genet. Genomics 273:54-65.

Gultyaeva, E.I., Dmitriev, A.P., Kosman, E. 2012. Regional diversity of Russian populations of Puccinia triticina in 2007. Can. J. Plant Pathol. 34:213-224.

Gultyaeva, E.I., Shaidayuk, E.L., Kazartsev, I.A., Aristova, M.K. 2015. Structure of Russian populations of Puccinia triticina Eriks. Plant Protection News 3:5-10.

Ishikawa, G., Nakamura, T., Ashida, T., Saito, M., Nasuda, S., Endo, T.R., Wu, J., Matsumoto, T. 2009. Localization of anchor loci representing five hundred annotated rice genes to wheat chromosomes using PLUG markers. Theor. Appl. Genet. 118:499-514.

Kant, L., Mani, V.P., Gupta, H.S. 2008. Winter $\times$ spring wheat hybridization - A promising avenue for yield enhancement. Plant Breed. 120:255-258.

Kiseleva, A.A., Shcherban, A.B., Leonova, I.N., Frenkel, Z., Salina, E.A. 2016. Identification of new heading date determinants in wheat 5B chromosome. BMC Plant Biol. 16 (Suppl. 1):8.

Kolmer, J.A., Kabdulova, M.G., Mustafina, M.A., Zhemchuzhina, N.S., Dubovoy, V. 2015. Russian populations of Puccinia triticina in distant regions are not differentiated for virulence and molecular genotype. Plant Pathol. 64:328-336.

Lapochkina, I.F., Baranova, O.A., Shamanin, V.P., Volkova, G.V., Gainullin, N.R., Anisimova, A.V., Galinger, D.N., Lazareva, E.N., Gladkova, E.V., Vaganova, O.F. 2016. The development of initial material of spring common wheat for breeding for resistance to stem rust (Puccinia graminis Pers. f. sp. tritici), including race Ug99, in Russia. Vavilov J. Genet. Breeding 20:320-328.

Mains, E.B., Jackson, H.S. 1926. Physiological specialization in the leaf rust of wheat, Puccinia triticina Erikss. Phytopathol. 16:89-120.

Mallick, N., Vinod, S.J.B., Sharma, J.B., Tomar, R.S., Sivasamy, M., Prabhu, K.V. 2015. Marker-assisted backcross breeding to combine multiple rust resistance in wheat. Plant Breed. 134:172-177.

McIntosh, R.A., Yamazaki, Y., Dubcovsky, J., Rogers, J., Morris, C., Appels, R., Xia, X.C. 2013. Catalogue of Gene Symbols for Wheat. http://www.shigen.nig.ac.jp/wheat/komugi/genes/symbolClassList.jsp

Miedaner, T., Korzun, V. 2012. Marker-assisted selection for disease resistance in wheat and barley breeding. Phytopathol. 102:560-566. 
Morgounov, A.I., Vlasenko, V.A., McNab, A., Braun, H.J. 1996. Wheat breeding: Objectives, methodology, and progress. http://repository.cimmyt.org/

Morgounov, A., Ablova, L., Babayants, O., Babayants, L., Bespalova, L., Khudokormov, Zh., Litvinenko, N., Shamanin, V., Syukov, V. 2011. Genetic protection of wheat rusts and development of resistant varieties in Russia and Ukraine. Euphytica 179:297-311.

Nowak, M., Leśniowska-Nowak, J., Zapalska, M., Banaszak, Z., Kondracka, K., Dudziak, K., Kowalczyk, K. 2014. Analysis of VRN1 gene in triticale and common wheat genetic background. Scientia Agricola 71:345-355.

Olson, E., Brown-Guedira, G., Marshall, D., Stack, E., Bowden, R.L., Jin, Y., Rouse, M., Pumphrey, M.O. 2010. Development of lines with a small introgressed segment carrying stem rust resistance gene $\mathrm{Sr} 22$. Crop Sci. 50:1823-1830.

Peterson, R.F., Campbell, A.B., Hannah, A.E. 1948. A diagrammatic scale for estimating rust intensity of leaves and stem of cereals. Can. J. Research Sect. C 26:496-500.

Petrash, N.V., Leonova, I.N., Adonina, I.G., Salina, E.A. 2016. Effect of translocations from Aegilops speltoides Tausch on resistance to fungal diseases and productivity in common wheat. Rus. J. Genet. 52:12531262.

Pugsley, A.T. 1971. A genetic analysis of spring-winter habit in wheat. Austr. J. Agric. Res. 22:21-31.

Rizza, F., Karsai, L., Morcia, K., Badeck, F.W., Terzi, V., Pagani, D., Kiss, T., Stanca, A.M. 2016. Association between the allele compositions of major plant developmental genes and frost tolerance in barley (Hordeum vulgare L.) germplasm of different origin. Mol Breed. 36:156-172.

Roelfs, A.P., Singh, R.P., Saari, E.E. 1992. Rust diseases of wheat: concepts and methods of disease management. CIMMYT. Mexico.

Salina, E.A, Adonina, I.G., Badaeva, E.D., Kroupin, P.Yu., Stasyuk, A.I., Leonova, I.N., Shishkina, A.A., Divashuk, M.G., Starikova, E.V., Khuat Thi Mai, L., Syukov, V.V., Karlov, G.I. 2015. A Thinopyrum intermedium chromosome in bread wheat cultivars as a source of genes conferring resistance to fungal diseases. Euphytica 204:91-101.

Sanin, S.S., Nazarova, A.N. 2010. The phytosanitary situation in the wheat fields in the Russian Federation (1991-2008). Plant Protection and Quarantine 2:70-78. (in Russian)

Sharma, S., Chaudhary, H.R. 2009. Combining ability and gene action studies for yield-contributing traits in crosses involving winter and spring wheat genotypes. Acta Agronomica Hungarica 57:417-423.

Shcherban, A.B., Efremova, T.T., Salina, E.A. 2012. Identification of a new Vrn-B1 allele using two near-isogenic wheat lines with difference in heading time. Mol. Breed. 29:675-685.

Shcherban, A.B., Börner, A., Salina, E.A. 2015. Effect of $V R N-1$ and $P P D-1$ genes on heading time of European bread wheat cultivars. Plant Breed. 134:49-55.

Somers, D.J., Isaac, P., Edwards, K. 2004. A high-density microsatellite consensus map for bread wheat (Triticum aestivum L.). Theor. Appl. Genet. 109:1105-1114.

Song, Q.J., Shi, J.R., Singh, S., Fickus, E.W., Costa, J.M., Lewis, J., Gill, B.S., Ward, R., Cregan, P.B. 2005. Development and mapping of microsatellite (SSR) markers in wheat. Theor. Appl. Genet. 110:550-560.

Sutka, J. 2001. Genes for frost resistance in wheat. Euphytica 119:167-172.

Timonova, E.M., Leonova, I.N., Röder, M.S., Salina, E.A. 2013. Marker-assisted development and characterization of a set of Triticum aestivum lines carrying different introgressions from the T. timopheevii genome. Mol. Breed. 31:123-136.

Witcombe, J., Virk, D. 2001. Number of crosses and population size for participatory and classical plant breeding. Euphytica 122:451-462.

Xu, Y. 2010. Molecular Plant Breeding. CAB International. Cambridge, MA, USA.

Yan, L., Helguera, M., Kato, K., Fukuyama, S., Sherman, J., Dubcovsky, J. 2004. Allelic variation at the $V R N-1$ promoter region in polyploid wheat. Theor. Appl. Genet. 109:1677-1686. 